French nuclear power

\section{Testing time for reactors}

The problem with French nuclear power stations is that three-quarters of them are less than three years old, and suffering from teething problems, according to Electricité de France (EDF), which owns and runs them.

What is not clear is whether this should be a comforting or a disquieting thought. French nuclear power production is supposed to be increasing, but in September EDF produced only $6,700 \mathrm{GWh}$ of electrical energy, compared with $8,200 \mathrm{GWh}$ a few months previously. The net availability - the proportion of energy delivered to nominal capacity - fell to below 50 per cent in the summer, compared with a typical industry target of 70 per cent and a world average for pressurized water reactors (PWRs) (according to EDF) of 60 per cent. But, says EDF, PWRs more than three years old had the magic 70 per cent availability. It was the young ones - an independent design series of 20 or 50 - that were in trouble.

The accompanying figure reveals how much of the French nuclear power

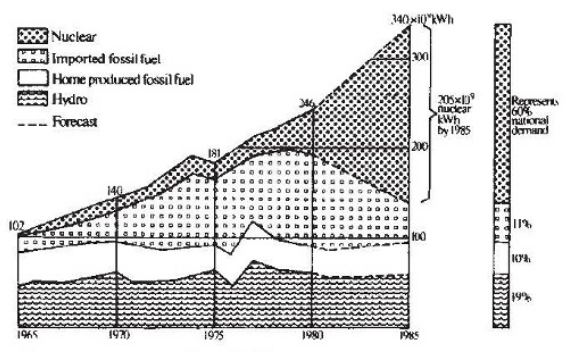

Power consumption in France

programme is indeed young, coming on line during 1980-85. This is literally a testing time for French nuclear power. Of the 22 reactors now connected to the grid, only 6 were connected before 1980 . Seven were connected that year, seven in 1981, and two have been connected this year. However, another 30 are under construction, due to come on line during 1983-89.

According to EDF, the problems amount to a combination of technical teething troubles and government safety regulations. There are three issues: a concentration of seven four-month shutdowns for obligatory inspections, after 18 months' operation, compared with four such shut-downs in 1981 and two planned for 1983; and two problems with faulty materials in the younger reactors.

One of these problems is outside the nuclear part of the reactor, in the steam "drier-superheater". This halted two reactors, Saint-Laurent B1 and B2, for a considerable period, but the problem is now thought to have been solved for these reactors and others in their production series.

The more awkward problem is the stresscorrosion cracking of inconel clips holding

\section{US defence}

guide tubes for the control rods within the reactor vessel. The problem was first noted in Japan in 1979, and since then the clips have undergone redesign in French reactors beginning construction. But most reactors coming on line in the past three years have the old clips, and there have been failures and shut-downs this year at Fessenheim 1, Bugey 2 and 4 and Gravelines 1 . The clips are to be replaced on a series of 20 reactors, at a net cost, according to EDF, of aboui FF 1,300 million ( $£ 110$ million).

But is this the end of the "teething" troubles - or will there be more to come, when the problem, like the clips and the

\title{
Townes in dissent on MX siting
}

\section{Washington}

Controversy continues about how and where the new MX missiles should be based. President Reagan is committed to give Congress a plan for basing the MX (short for "missile experimental") by 1 December and the Secretary of Defense, Mr Caspar Weinberger, has done his part by transmitting his recommendations to the White House, apparently on 1 November. But now his most prominent scientific adviser on the issue, Dr Charles Townes of the University of California at Berkeley, has taken the unusual step of expressing his personal doubts about the now-favourite plan - and the contents of his letter have been promptly leaked in the US press.

The question of how to deploy MX has been a long-standing conundrum. Out of about 30 alternative plans suggested by the military, the Carter Administration selected that called "Racetrack" in which missiles would have been moved from one launching point to another by means of underground tunnels. But by the time the plan was put forward, so many doubts had arisen that Congress never approved it.

The same fate may yet await the Reagan Administration, which has already failed to persuade Congress to authorize funds for deployment - without specifying how the missiles would be deployed. Townes was appointed head of a panel of scientists and defence experts to re-examine the MX problem when $\mathrm{Mr}$ Weinberger took office. The scheme now most favoured by the US Air Force and, it is rumoured, by $\mathrm{Mr}$ Weinberger is called "Dense Pack". MX missiles would be placed in fixed and hardened canisters in the ground so close together that incoming warheads would interfere with each other, the blast and other consequences of a nuclear explosion interfering with later arrivals.

The Air Force now says that $100 \mathrm{MX}$ missiles separated by distances of about 2,000 feet would be close enough to ensure drier-superheaters, will be multiplied through a long production series leading to high replacement costs, and a degree of insecurity in future electricity supply, which is planned to reach 60 per cent nuclear by 1985 ?

However, this can be taken as an argument for building more nuclear rectors, not less, to provide a cushion of overcapacity, and it will no doubt be taken that way at the ministry of research and industry in the forthcoming argument over coal and nuclear power and falling energy demand forecasts (see Nature 11 November, p.100). In Britain, too, where the Central Electricity Generating Board is planning its first PWR at Sizewell, Suffolk, the French problems are seen in a positive light - as useful design lessons. Robert Walgate

interference (called "fratricide" in the new jargon). Hitherto, the Air Force has discarded Dense Pack on the grounds that missiles not destroyed in an attack would be unable to fly out in retaliation. The new development is that the Air Force says that missile silos can be hardened so that their missiles will survive even if over-pressures amount to $5,000 \mathrm{lb}$ per square inch.

The nub of Townes's argument is that this "super-hardening" may not be feasible, that there are no clear limits on the time that would be needed for such a development or of its cost and that the Soviet Union might find a counter to Dense Pack sooner than the Air Force could install it.

Military considerations apart, Dense Pack has the political advantage that it would occupy an area of only 10-15 square miles. One of the objections to Racetrack from ranchers and environmentalists in western states was that huge tracts of land would be required.

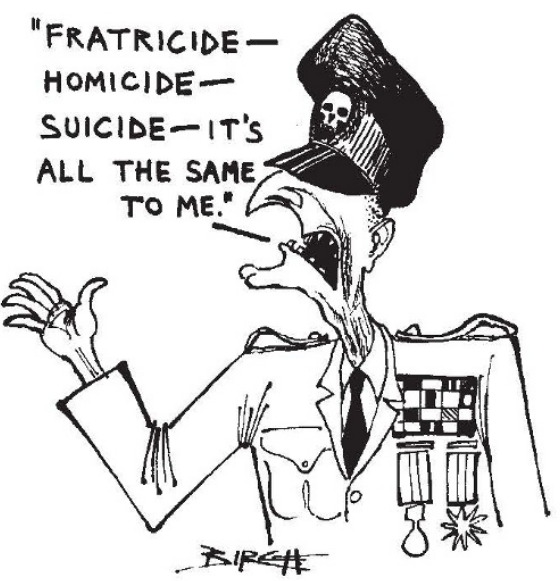

The latest version of Dense Pack advocated by the Air Force is that the 100 MX missiles would be sited in a long thin column aligned north to south. This has the theoretical advantage that the optimum pattern of an attack on the missile field 
from the Soviet Union, called a "walk attack", can be predicted: the most southerly rows of missiles would have to be attacked first and succeeding warheads would have to be aimed at suitable intervals at rows of missile silos sited further north. On this argument, a pattern of attack moving from north to south would be ineffective because later warheads would have to survive the atmospheric disturbance caused by the first nuclear explosion.

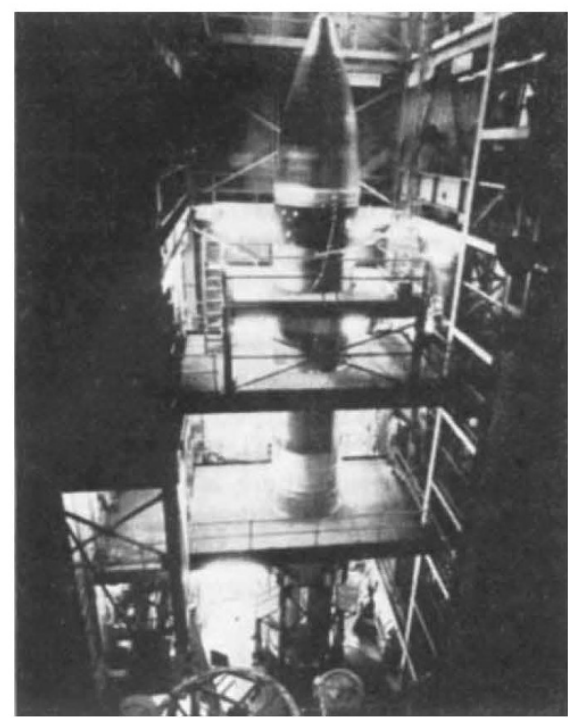

It is not clear what the consequences will be for Dr Townes now that his strong expression of personal doubt about the government plan has leaked into the press. Scientific advisers have run into trouble on such grounds on many previous occasions. But Dr Townes is much respected within the present Administration and his opinion may even help the President to reach a wiser decision by the beginning of next month.

Deborah Shapley

\section{Yes to toxin cloning \\ Washington}

The Recombinant DNA Advisory Committee (RAC) approved two controversial toxin-cloning experiments at its 25 October meeting, but ordered that they be carried out under P4 containment, the most stringent safety precaution available.

Dr John Murphy of Harvard Medical School, who in July 1981 received permission to clone the diphtheria toxin gene in Escherichia coli $\mathrm{K}-12$, will now be allowed to extend those experiments to linking the toxic gene with the gene that codes for melanocyte stimulating hormone. The aim is to generate a hybrid toxin molecule that selectively homes in on melanoma cells.

The experiments will have to be performed at the National Cancer Institute's laboratory at Frederick, Maryland, which is the only P4 facility in the country. Stephen Budiansky

German research and technology Waiting for the next election

Bonn

Dr Heinz Riesenhuber, appointed last month as West German federal minister for research and technology, seems to have made a good first impression. But it is also clear that between now and the promised general election next March, there will be time only for some modest if urgent housekeeping, and for planning how to put flesh on the bones of the promises of the past few weeks.

The federal ministry for research and technology has two immediate tasks - to win agreement on a budget for next year (and on a supplementary budget for 1982) within the caretaker government and with the parliament; and to put the two big prototype nuclear reactor projects on a sound financial basis. Both issues must be settled before the year is out, for thereafter all contentious issues will be overtaken by preparations for the election.

The budgetary and reactor issues are closely linked, for the reactor construction costs are a large part of the federal ministry's budget. There seems a good chance that the parliament (Bundestag and Bundesrat) will fall in with the previous government's proposal that the ministry should have a supplementary subvention of DM500 million ( $£ 116$ million) with which, for practical purposes, to liquidate bank loans taken out by participating electricity utilities to keep construction going. (The propriety of this device could nevertheless become a political issue at the election.) If the Christian Democrat government is re-elected, Dr Riesenhuber's belief that both reactors should be completed will nevertheless become a simplifying touchstone for future policy: although, as one high official emphasized last week, the government will not support the projects "at any price". But the new government seems to understand that new technology is never more expensive than when it is postponed.

The implications of Dr Riesenhuber's first-flush declaration that research and technology must share in the new government's commitments to a six per cent reduction of spending, but that "basic research" must at the same time be protected, are harder to discern. Some officials hope to find some relief from the strictest possible application of the six per cent rule in the caveat that it may not apply when the consequences would be legally invalid. Most of the ministry's projects entail agreements with constitutionally autonomous Länder governments for example, and may therefore be exempt. The budget for 1983 now being canvassed in the Bundestag, at just under DM7,000 million, is a reduction of DM 300 million on the original budget for 1982 - the first reduction since the ministry's creation in 1971. But it seems to be an article of faith that when economies are decided, they will not affect basic research.

Dr Riesenhuber's other memorable declaration, that the large national research laboratories should have a closer relationship with industry and that direct support for research and development should progressively be replaced by "indirect support", is for the time being equally uncertain in its implications. The minister's conviction that civil servants cannot adequately supervise the more than 6,000 direct-support projects now on his department's books is readily accepted, but nobody has a clear idea of what indirect support consists of. The notion that the federal government might subsidize the salaries of qualified scientists and engineers working for small and medium-sized companies is one being canvassed. By the general election, Dr Riesenhuber may have other cards up his sleeve. Meanwhile, he is committed to the award of a prize of DM30,000 at some point during 1983 to somebody working in a public laboratory making the most outstanding contribution to industry.

No doubt in the hope of avoiding similar problems with thermonuclear fusion, the federal ministry of research is planning to peg its total expenditure on fusion, principally at the Max Planck Institute at Garshing and the JET laboratory at Culham in the United Kingdom, to about DM200 million a year. It has been decided that Garshing will be concerned only with plasma physics machines, and that the nuclear research establishment at Karlsruhe will assume responsibility for any experiments in which thermonuclear fuel is consumed to produce radioactive materials.

Elsewhere, the prospect that a change of government may stimulate other changes seems now, as ever, frustrated by the constitution. Nobody thinks it feasible that the excess numbers of students at the most popular universities could be limited by some selection process, or even arbitrarily; the Länder would not stand for that. The federal ministry of education is nevertheless hoping to help cure the enforced immobility in academic life in the past few years with a proposal to spend DM50 million a year on the appointment of up to 1,000 newly graduated PhDs to one- or two-year posts in universities. This development, valuable in itself, is also a test of the federal government's undivided constitutional responsibility for research. The bill now before the Bundestag does not depend on the compliance of the Länder governments.

The education ministry, following the doctrine that basic research should be protected, has also managed to increase the budget of the Deutsche Forschungsgemeinschaft for next year by four per cent. 